\title{
Local Electoral Incentives and Decentralized Program Performance $^{1}$
}

\author{
Alain de Janvry, Frederico Finan, and Elisabeth Sadoulet \\ University of California at Berkeley
}

September 2009

\begin{abstract}
Central governments are increasingly delegating to local governments the implementation of social programs in hopes of improving their performance. Yet, for decentralized program implementation to be effective, locally elected officials must have an incentive to achieve high levels of performance. This paper analyzes how electoral incentives affect the performance of a major decentralized conditional cash transfer program intended on reducing school dropout rates among children of poor households in Brazil. We show that while this federal program successfully reduced school dropout by 8 percentage points, the program's impact was 36 percent larger in municipalities governed by mayors who faced reelection possibilities compared to those with lame-duck mayors. First term mayors with good program performance were much more likely to get re-elected. These mayors adopted program implementation practices that were not only more transparent but also associated with better program outcomes. Overall, our findings underscore the importance of electoral incentives for the decentralization of public goods provision.
\end{abstract}

JEL classification: D78, H43, I28, O15

Keywords: Decentralization; electoral incentives; conditional cash transfer; impact evaluation.

\footnotetext{
${ }^{1}$ We are indebted to Kathy Lindert, Bénédicte de la Brière, Donald Nelson, Lucia Chaves, Simone Cabral Marinho dos Santos, Irles Mayorga, and Julia Morim in helping us implement this research project, and to The World Bank, UNESCO, and DIFID for financial assistance in covering the cost of the survey.

Authors' addresses: Alain de Janvry, alain@are.berkeley.edu; Frederico Finan, ffinan@econ.berkeley.edu; Elisabeth Sadoulet, sadoulet@are.berkeley.edu.
} 


\section{Introduction}

Many countries have decentralized the implementation of public programs to locally-elected governments in seeking efficiency gains in performance (Bardhan, 2002). The expectation is that local governments have unique advantages in allocating public resources, such as access to information not available to central authorities and local social capital to enforce rules (Faguet, 2004). Moreover, local elections can be used to reward elected officials based on good program performance (Seabright, 1996; World Bank, 2003).

In practice, however, decentralized program implementation may not meet this expectation. Although the informational advantages associated with decentralization have been shown to exist (Alderman, 2002), use of this information for efficient program implementation depends on whether local governments can in fact be held accountable to constituents for their efforts. This remains an open question. The accountability of local governments to program stakeholders can be curtailed by the power of opportunistic elites (Rose-Ackerman, 1999) or by political institutions that do not give citizens the ability to discipline elected officials (Persson and Tabellini, 2002). For instance, term limits may curtail incentives for politicians to make efforts in providing high quality local public goods when they can no longer seek re-election (Besley, 2006). Local politicians' performance in program implementation would thus depend on existence of electoral incentives for them to make good use of the informational advantages they possess.

In this paper, we investigate the extent to which local electoral incentives affect the level of impact of a major decentralized conditional cash transfer (CCT) program in Brazil - Bolsa Escola - designed to reduce school dropout among the children of the poor. Although Bolsa Escola, now part of a broader program called Bolsa Familia, was a federal program, municipal governments were responsible for identifying beneficiaries and enforcing conditionalities. This created substantial variation across municipalities in the manner in which the program was implemented and in its impact. Using an extensive dataset that combines a municipal survey with school records for 290,517 children over the period 1999 to 2003 (with two years before the program and three years under the program), we estimate the program's impact on primary and secondary school dropout rates for each of 261 municipalities in the Northeast of Brazil. We then identify the impact of municipal electoral incentives on local politicians' program performance by measuring the difference in achievement between first and second-term mayors, and in particular between first term mayors who were subsequently re-elected and second term mayors. While many studies in constitutional economics have posited the importance of electoral incentives for 
effective decentralized service delivery (World Bank, 2003), this study is among the first to support this empirically.

We find that while, on average across municipalities, the program reduced dropout rates during the school year by 8 percentage points, there was considerable variation across municipalities. Municipalities governed by a first-term mayor eligible for re-election had an estimated 36 percent higher program performance compared to municipalities governed by a second-term mayor who is, by constitutional law, not eligible for re-election. This difference persists when comparing second-term mayors to first-term mayors that got re-elected in the subsequent election, thus controlling for revealed ability, and to mayors with a comparable level of political experience.

Using municipal level election data, we show that first-term mayors had reason to care about good program performance. The probability of re-election was 28 percent higher for mayors who were in the top quartile of program impacts. Mayors with no public denouncements of inclusion errors were also rewarded with a 26 percent higher probability of re-election. We show that a number of good management practices related to transparency that affect program performance were more frequently associated with first than second-term mayors, indicating how better performance actually came about.

Our findings contribute to a growing empirical literature in constitutional economics that emphasizes the importance of electoral accountability in aligning politicians' actions with voters' preferences. Foster and Rosenzweig (2004) show that local democratization works in Indian villages in that greater electoral competition in controlling governing bodies and a higher share of poor landless in the voting population increase the allocation of public budgets toward pro-poor local public goods. Besley and Case (1995) show that re-election incentives affect the fiscal policy decisions of U.S. governors while List and Sturm (2006) provide evidence that term limits influence environmental policy. Using the outcomes of random audits of municipal finances in Brazil, Ferraz and Finan (2008) show that mayors that face re-election incentives are significantly less corrupt than mayors without such incentives. While both the Ferraz-Finan and this paper analyze the role of local electoral incentives on politicians' performance, the papers differ in a complementary fashion: the first focuses on rents extracted via corruption practices while the second focuses on efforts made in achieving program performance.

Much of the empirical work on the effectiveness of decentralized service delivery has focused on how decentralized programs are targeted, due in large part to the fact that measures of program performance were unavailable. For instance, Alderman (2002) has shown that the local level informational advantage has been used by local authorities in Albania to better target the 
poor. Galasso and Ravallion (2005) for public food-for-school transfers in Bangladesh and Bardhan and Mookherjee (2006) for credit and agricultural input kits in West Bengal villages found that the degree of local pro-poorness in decentralized targeting is affected by program and village features. But ultimately what we care about is the impact of the program, and targeting may not be a good indicator of program performance (Ravallion, 2007)). Our paper,which complements this literature, is the first empirical study to show how the performance of a decentralized program is affected by local institutions, and particularly those that help establish local accountability.

The paper is organized as follows. In section II, we propose a model of local electoral incentives that highlights the differences in effort in program implementation between first-term and second-term mayors. In section III, we present the features of the Bolsa Escola program and review results obtained in previous evaluations. In section IV, we explain the data collection and give descriptive statistics on dropout rates across municipalities. We explain the method for measuring program impact at the municipality level in section V. We then report in section VI results on the impact of Bolsa Escola on dropout rates. In section VII, we give estimates of the gains in performance due to electoral incentives. In section VIII, we interpret the results first by verifying that electoral rewards do accompany good program performance and second by exploring how first term mayors achieve superior program performance. We conclude in section IX on the benefits of electoral incentives for decentralized program performance.

\section{A model of local electoral incentives}

In this section, we construct a simple political economy model to show the role of electoral incentives on program performance when performance depends on efforts made by an elected municipal official. The program is one where an exogenous quota of school stipends is transferred to a municipality that must select beneficiaries among qualifying households, with the number of stipends received inferior to the number of qualifying children. Because qualifying children are heterogeneous in their responses to the offer of a stipend, the impact of the program is largely due to the selection of beneficiaries. The central government's objective is to reduce the school dropout while the local government's objective is re-election with a two-term limit. Voters are informed of and concerned with municipal program performance. The local electorate can 
thus reward for good performance local politicians who are up for re-election. Improving program performance requires costly effort on their part but increases their chance of re-election. ${ }^{2}$

Following the model set up, the local government must decide whether a child $i$ with characteristics $z_{i}$ is selected or not $\left(P_{i} \in\{0,1\}\right)$, given the number of stipends $B$ allocated to the municipality. The expected program's impact $\theta_{i}=\theta\left(z_{i}\right)$ on the school performance of child $i$ depends on his characteristics. The program's impact in the municipality is $\bar{\theta}=\sum_{i} P_{i} \theta\left(z_{i}\right)$.

From the perspective of the program itself, maximum impact is obtained by giving beneficiary status to children with the highest $\theta_{i}$, in descending order until the municipal quota is reached. However, this first best outcome may be difficult to achieve for at least two reasons. First, the objectives of the program and of the mayor may not be entirely aligned. Second, even if the mayor was concerned with maximizing program effectiveness in reducing dropout, to correctly anticipate a child's response to the program requires levels of administrative ability and effort that the mayor may not have or provide.

To formalize these possibilities, consider a two-period model where citizens choose at the end of the first period whether to re-elect the incumbent mayor or not. Voters care about the program's impact $\bar{\theta}(a, e, z, B)$, which is influenced by both the mayor's ability $a$ and effort $e$, with first derivatives $\bar{\theta}_{a}$ and $\bar{\theta}_{e}$ positive, respectively. The mayor's own utility is also function of his direct reward $R$ from beneficiary selection that can be written as $R(a, e, z, B)$, decreasing in effort $R_{e}<0$. To simplify further the derivation of the model, we assume that the program impact is $\bar{\theta}=g(z, B)+a+e$, and the politician's utility is $R-\psi(e)$, with $\psi_{e}>0, \psi_{e e}>0$. As defined here, $e$ represents the effort exerted by the mayor in both the selection of beneficiaries and/or the administration of the program. Although more effort does increase the program's impact, the mayor experiences a disutility from exerting effort.

The timing of events is as follows. First the mayor selects the beneficiaries. His ability to select beneficiaries is a random variable $a_{1} \sim N\left(\bar{a}, \sigma_{a}^{2}\right)$, unknown even to him in the first period. He chooses the amount of effort to exert in increasing the impact of the program. At the end of

\footnotetext{
${ }^{2}$ The model is an adaptation of the standard political agency model found in Barro (1970), Ferejohn (1986), Banks and Sundaram (1993), and recently Alesina and Tabellini (2007). The basic insight from this class of models is that in a political context in which elections reward politicians' performances, incumbents with reelection possibilities have the incentive to exert effort in the implementation of the program in order to increase their re-election chances.
} 
the first period, voters observe the outcome $\bar{\theta}_{1}$, but not its decomposition between ability and effort. Based on this observation, they decide on whether to re-elect the incumbent or not. If the incumbent is re-elected, his ability is maintained. Otherwise, a challenger comes in with an ability randomly drawn from the distribution of abilities. In period 2, the mayor chooses again the level of effort to exert, thus determining the impact $\bar{\theta}_{2}$ of the program for that period.

Because the game ends in period 2, there is no electoral incentive for mayors to exert any effort in the second period. So program impact in the second period is $g(z, B)+a_{1}$ if the incumbent is reelected, and expected impact is $g(z, B)+\bar{a}$ otherwise. Unable to induce politicians to exert effort, voters will seek to elect the most able mayor. The incumbent is reelected if the impact exceeds a threshold $W$ corresponding to the outcome expected from the average politician.

The first-term mayor's inter-temporal objective is:

$$
\max _{e} R-\psi(e)+\operatorname{Pr}\left(\bar{\theta}_{1} \geq W\right) R \text {. }
$$

The optimal effort $e^{*}$ is the solution to $\psi_{e^{*}}=R \varphi\left(W-g(z, B)-e^{*}\right)$, where $\varphi$ is the density function of ability. The mayor sets his effort to equate the current marginal cost of not using the program for his own benefit to the future marginal benefit of being re-elected.

Rational voters know that they should expect this optimal level of effort $e^{*}$ and corresponding outcome $W=g(z, B)+\bar{a}+e^{*}$ from the average politician. They will vote the incumbent in if the observed outcome is higher than the expected outcome, $\bar{\theta}_{1} \geq W$. Substituting the expression for $W$, the optimal effort of the first term mayor is the solution to:

$$
\psi_{e^{*}}=R \varphi(\bar{a}) .
$$

The corresponding program impact of a first term mayor is:

$$
\bar{\theta}_{1}=g(z, B)+a_{1}+e^{*},
$$

greater than the second term impact, if he is re-elected:

$$
\bar{\theta}_{2}=g(z, B)+a_{1} \text {. }
$$

The intuition for this result is straightforward. When faced with the possibility of reelection, incumbent politicians will exert more effort to increase the program's impact. Thus, given the theory, we would expect the program to perform better in municipalities with mayors who have re-election incentives relative to those with mayors who do not. This is the main testable prediction that we take to the data. 
While our model predicts that the program will perform better in municipalities governed by mayors with re-election incentives, there are alternative specifications that provide the opposite prediction. Three possibilities are the roles of ability, experience, and clientelism. If, for instance, our model only captured a mayor's ability (and ability was revealed after taking office), then re-election would serve as a screening device for high-ability mayors. In this case, the program would perform better in municipalities with second-term mayors, who on average would be more able than first-term mayors. While this is certainly a possibility, our results suggest that the program performed better in municipalities governed by first-term mayors. This says that the observed superior program performance in the first term has to come from electoral incentives even if elections serve in improving second-term performance through screening on ability. The same would apply to the accumulation of experience in selection as a mayor progresses from first to second term. Performance would be superior among second term mayors: an effect opposite to that of electoral incentives.

Implicit in our model is the assumption that voters care about the program's impact. Voters, however, may only care about whether they themselves are program beneficiaries. In this case, the incentive politicians have to target the program might be quite different from those presented in the model. In fact, mayors who face re-election possibilities may prefer to target potential swing voters regardless of their children's risk of dropping out of school in order to garner support from this group (Besley and Kanbur, 1993). In this case, the program would perform worse in municipalities with first-term mayors. Here again, observing better first-term program performance has to come from electoral incentives even if elections induce first-term clientelism games.

\section{The Bolsa Escola program}

Primary and secondary education are compulsory in Brazil for children ages 6 to 15 and, as a consequence, enrollment at the beginning of the school year is almost universal (Souza, 2005). But high enrollment rates hide a major problem in that a large number of children dropout of school during the school year, only to re-enroll in the following year as required by law. This induced the Brazilian government to introduce an educational CCT program, Bolsa Escola, that offered mothers in poor households a monthly stipend conditional on their children ages 6 to 15 attending school on a regular basis. Households with a monthly per capita income of less than 90 Reais (around \$40) were eligible. The transfer was R15 per child with a maximum of R45 per 
household. ${ }^{3}$ While the eligibility and conditionality rules were similar to those of other educational CCT programs such as Mexico's Oportunidades, a distinguishing feature of the Bolsa Escola program is that it was decentralized at the municipal level. Each municipality received a quota of stipends it could provide to its population. This quota was determined on a formula basis using indicators from the 1996 population census. Municipalities were responsible for identifying all households below the poverty line with children that met the program's requirements. Because the number of qualified households generally exceeded the quota, it was also the municipality's responsibility to select program beneficiaries among qualifying households. Municipalities were entrusted with enforcing the school attendance conditionality. The program was implemented across all of Brazil in 2001 and incorporated in 2004 into the broader Bolsa Familia program with little substantive change (Lindert, Linder, Hobbs, and de la Brière, 2006).

Bolsa Escola was first conceived in the Federal District of Brasilia and extended to cities like Recife, before being scaled up into a national program. Two studies have analyzed these earlier forms of the program. For the Federal District, Abramovay, Andrade, and Waiselfisz (1998) found that dropout rates were 7 percentage points lower for beneficiary children than for children of non-beneficiary families. For the city of Recife, Aguiar and Araújo (2002) found that dropout rates were 0.4 percent among beneficiaries in 1996 compared to 5.6 percent among nonbeneficiary children, a gain of 5.2 percentage points. These results are of the same order of magnitude as those which we report here even though these early programs were somewhat different from the federal program as transfers were higher and the program's requirements were weakly enforced. Using municipal-level data, Glewwe and Kassouf (2008) find that Bolsa Escola once extended at the national scale reduced dropout rates by about 8 percentage points for children in grades 1-4 but did not impact the dropout rates of children in grades 5-8. ${ }^{4}$

The present evaluation of Bolsa Escola uses a rigorous identification of impact based on observed individual child responses to the incentives provided by the CCT. Measurements are obtained both overall and for each municipality for the 2001-2003 period. We then use these measures of municipal performance to analyze the importance of electoral incentives and of local governance practices on observed outcomes. Identification of electoral incentives on performance is provided by the fact that introduction of Bolsa Escola in 2001 happened exogenously relative

\footnotetext{
${ }^{3}$ As a comparison, the minimum wage was R240 per month.

4 Bourguignon, Ferreira, and Leite (2003) provided an ex-ante evaluation of Bolsa Ecola. Using a simulation model based on observed child schooling responses to labor market wages estimated from the PNAD data, they find that over 50 percent of the children of poor households would respond to the incentives of the program. This implies halving the pre-program dropout rate, again a result not far from our own estimates.
} 
to the first or second term status of the current mayor. Electoral outcomes are observed in the subsequent municipal election held in 2004.

\section{Data and descriptive statistics}

Data collection for the project took place between October and December of 2004 in 261 municipalities randomly selected across the states of Ceará, Pernambuco, Paraíba, and Rio Grande do Norte in the Brazilian Northeast. ${ }^{5}$ In each of the 261 municipalities, two data collection instruments were applied - compilation of school records and a municipal survey -, complemented by secondary data on the municipality regarding Bolsa Escola payment records and electoral outcomes.

\section{School records}

To properly measure the effects of Bolsa Escola on school attendance, we collected in each municipality school records for at least 500 children over the 1999-2003 period. ${ }^{6}$ To gather these records, one or two schools were randomly drawn proportionately to the number of Bolsa Escola recipients (this number was obtained from the payments records of the Ministry of Education) within each selected municipality. Information on the enrollment status of each child in the school was compiled from the annual class reports filled in by teachers. Matching records across school years was done manually using children's first and last names, allowing us to match 85 percent of the collected records. ${ }^{7}$ In total, we can follow the school performance for 290,517 children in primary and secondary school over part or all of five years, giving us 604,561 data points. $^{8}$

In the class reports, teachers provide the full list of students who started the year, and then indicate, by the end of the year, if a child has passed the grade, failed the grade, transferred

\footnotetext{
${ }^{5}$ The municipalities of these four states were stratified according to their land inequality, size of public sector, and quota of program beneficiaries; and were randomly sampled from 8 strata. The sample was stratified to capture sufficient variation along variables that may be correlated with governance and importance of the program.

${ }^{6}$ The school year in Brazil runs from February to December. We thus observe two complete years before the program (1999 and 2000) and three complete years with the program (2001 to 2003).

${ }^{7}$ The remaining 15 percent include cases where the child either left school without this being recorded; or the child's name was simply changed, incomplete, or unreadable. With no discernable pattern in the occurrence these cases across grades, it is unlikely that any of these reasons could be correlated with being a stipend recipient. Also restricting the estimation to the balanced-panel of children yields similar results.

${ }^{8}$ The target was to have at least 500 current students per municipality, which led to an average of 1100 students in the school records as many schools are large and we collected information on all students attending school at any point in time during the 1999-2002 period.
} 
to another school, dropped out of school, or died. ${ }^{9}$ Table 1 shows the magnitude of the school dropout problem that Bolsa Escola was designed to address. In 2000, before the program started, 15 percent of the children dropped out of school during the course of the year. But, because school is compulsory, 98 percent of them registered again in school in some later year even among Bolsa Escola non-beneficiaries.

Although administrative records have the advantage of greater accuracy than selfreported information on attendance and grade promotion, not having conducted household interviews results in at least two shortcomings. First, we do not have information on children and household characteristics. And while the use of child fixed-effects eliminates any biases associated with our inability to control for time invariant characteristic of the child and his family, lack of information prevents us from exploring how the impacts vary according to these characteristics. Moreover, we cannot investigate whether the program was targeted according to certain observable characteristics of children, other than their prior school attendance and achievement status. Secondly, we cannot follow children who transfer out of the school. However, we can observe if the child transferred to another school (as opposed to being reported as missing school), and we see that less than four percent of the children had transferred. In the analysis that follows, we simply remove these children from the sample.

\section{Bolsa Escola eligibility and beneficiary status}

In our school visits, teachers were asked to identify what percentage of children was eligible for Bolsa Escola. In every school, teachers identified more than 97 percent of the children as qualifying for the program. ${ }^{10}$ We therefore consider all the children as eligible. As we will see later, the identification strategy does not depend on strict eligibility of all children.

We obtained the complete list of beneficiaries from the Bolsa Escola federal office for the years 2001 and 2002. For each household, records include parents' and children's names, and the school attended by the child. Matching these beneficiaries to the school information gives the beneficiary status of all the children in the school records. Matching was again done manually using children's full names (last names of both parents and first name of the child). Beneficiary status in 2003 can safely be assumed to be the same as in the previous two years as no reselection was undertaken in that or prior years.

\footnotetext{
${ }^{9}$ The class records are not electronic and not shared with Bolsa Escola. They do not report on daily school attendance to meet Bolsa Escola conditionality, where cheating could occur.

${ }^{10}$ That 97 percent of the children were qualified for the program is not surprising given both the public school system in Brazil, which is almost exclusively attended by poor children, and the fact that we sampled schools with probability proportional to the number of Bolsa recipients. The Northeast of Brazil is also the region with the highest incidence of poverty.
} 
We have no independent information to confirm the non-beneficiary status of children in the school records that we could not match with the Bolsa Escola list, and we could not match $25 \%$ of the Bolsa Escola list into school records. Matching errors may thus entail beneficiary children misclassified as non-beneficiaries. This would imply that we estimate a lower bound for the impact of the program.

\section{Municipal data}

The municipal survey contained several parts designed to gather general information on municipal and mayor characteristics and governance practices, and implementation methods for the Bolsa Escola program. Designated respondents for the various sections of the questionnaire were mostly public administrators, but also included politicians and key members of civil society, such as the local priest or the president of the labor union. For questions on Bolsa Escola, we interviewed the corresponding program coordinator about how the municipality identified and selected beneficiaries, and monitored and enforced the conditionalities.

Overall we found considerable variation across municipalities in the procedures used to identify and register potential beneficiaries. Differences relate to where the registration of potential beneficiaries took place, whether efforts were made to verify the information given by parents, and whether the municipality had social councils that could engage in deliberating program implementation. ${ }^{11}$ The number of potential beneficiaries largely exceeded the quota of stipends that was allocated to the municipality by the federal government. On average, an estimated 49 percent of eligible households were left out of the program, leaving it to the municipality to select the beneficiaries from among the pool of eligible households. There was also variation in implementing conditionalities across municipalities. While most municipalities reported monitoring the school attendance conditionality, this was done more strictly in some municipalities than others, with program coordinators visiting households in some municipalities to assess familial conditions when conditionalities were not met instead of strict imposition of financial penalties in others. Our survey thus revealed a great deal of heterogeneity across municipalities in program implementation despite definition of rules at the federal level.

In addition to information on program implementation, the survey was also designed to document governance practices. For instance, in our sample of municipalities, we found that in 25 percent of the municipalities, more than 15 percent of the employees in the mayor's office were related to the mayor, and in 12 percent of the municipalities, the mayor's spouse was also an

${ }^{11}$ See de Janvry, Finan, Sadoulet, Nelson, Lindert, de la Brière, and Lanjouw (2005) for details on these procedures. 
elected politician. Across municipalities, 47 percent of the administrative positions were held by political appointees rather than technocrats. ${ }^{12}$

\section{Measuring program performance}

In this section, we present the econometric specifications used to estimate the impact of the Bolsa Escola program on dropout rates. Given the data and research design, the impact of the program on beneficiaries can be estimated for every municipality in the sample. It is this program impact that provides a measure of municipal program performance for the analysis of electoral incentives.

With decentralized implementation, beneficiaries are selected by the municipality. Because choice is exercised, there is no reason to expect that beneficiaries are strictly comparable to non-beneficiaries. To illustrate this selection process, the last rows of Table 1 report preprogram performance of the future Bolsa Escola beneficiaries and non-beneficiaries. Beneficiaries were clearly not selected at random. Their pre-program dropout rates are less than a third that of non-beneficiaries.

The empirical strategy to measure the effect of Bolsa Escola on the selected beneficiaries for each municipality uses panel data on children before and after the start of the program, and proceeds with a number of tests to verify robustness of the results.

We start with a standard difference-in-difference model where schooling outcome for child $i$ in municipality $j$ in period $t$ is modeled as:

$$
S_{i j t}=\phi_{i j}+X_{i j t} \beta+\theta_{i j} P_{i j t}+\varepsilon_{i j t} \text {, }
$$

where $S_{i j t}$ is schooling outcome (dropout), $\phi_{i j}$ is an individual fixed effect, $X_{i j t}$ are time varying observables including year fixed effects, and $P_{i j t}$ is an indicator for program participation. ${ }^{13} \theta_{i j}$ is a random coefficient that measures the gain for individual $i j$ from participating in the program, and $\varepsilon_{i j t}$ an unobserved shock to schooling assumed unrelated to program participation conditional on $X_{i j t}$.

With this model for individual behavior, the treatment on the treated (TT) effect in municipality $j$ is given by:

\footnotetext{
12 Throughout Brazil's political history, there has been a clear distinction between political appointees or "traditional politicians" and technocrats (técnicos) who are appointed individuals with non-political backgrounds (see Hagopian, 1996),

${ }^{13}$ There is no distinction between participating in the program and being offered the program because takeup rates are 100 percent.
} 


$$
\bar{\theta}_{j}=E\left(\theta_{i j} \mid B_{i j}=1\right)
$$

where the conditioning on $B_{i j}=1$ denotes that the individual $i j$ is a beneficiary. This expression highlights the sources of differentiation in average $T T$ effects across municipalities. Municipal treatment effects may thus differ due to both their selection of beneficiaries from amongst the population and the distribution of individual effects $\theta_{i j}$ in their eligible population.

The validity of this identification strategy relies on the strong assumption that, conditional on individual fixed-effects, the trend in future dropout behavior of beneficiaries and non-beneficiaries would be the same in the absence of the Bolsa Escola program. Given that the process of selection of beneficiaries was done only once at the onset of the program in 2001, the concern is not that beneficiaries could be brought into the program in response to unanticipated shocks after the program had started. The main concern is that the selection decision was based on pre-program schooling outcomes.

To address this concern, we include in $X_{i j t}$ differential time effects by pre-program dropout histories $S_{i j 0}$ which are the best predictors of future dropout behavior. The estimation of $\bar{\theta}_{j}$ can be obtained by rewriting equation (1) as follows:

$$
S_{i j t}=\phi_{i j}+\beta_{j t}+\gamma_{j t} S_{i j 0}+\left[\bar{\theta}_{j}+\theta_{j}^{*}\left(S_{i j 0}-\bar{S}_{j 0}\right)\right] P_{i j t}+\mu_{i j t} \text {, }
$$

where $\mu_{i j t}=\left(\theta_{i j}-\bar{\theta}_{j}-\theta^{*}\left(S_{i j 0}-\bar{S}_{j 0}\right)\right) P_{i j t}+\varepsilon_{i j t}, \quad \theta_{j}^{*}=E\left(\theta_{i j} \mid B_{i j}=1, S_{i j 0}=1\right)-E\left(\theta_{i j} \mid B_{i j}=1, S_{i j 0}=0\right)$, $\bar{S}_{j 0}=E\left(S_{i j 0} \mid B_{i j}=1\right)$ and $\beta_{j t}$ and $\gamma_{j t} S_{i j 0}$ denote different sets of year effects.

The estimator is consistent if $\mathrm{E}\left(\left(\theta_{i j}-\bar{\theta}_{j}-\theta^{*}\left(S_{i j 0}-\bar{S}_{j 0}\right)\right) P_{i j t}+\varepsilon_{i j t} \mid \phi_{i j}, \beta_{j t}, \gamma_{j t} S_{i j 0}, P_{i j t}\right)=0$. The first term $\mathrm{E}\left(\left(\theta_{i j}-\bar{\theta}_{j}-\theta^{*}\left(S_{i j 0}-\bar{S}_{j 0}\right)\right) P_{i j t} \mid \phi_{i j}, \beta_{j t}, \gamma_{j t} S_{i j 0}, P_{i j t}\right)$, which accounts for the difference between the child specific effect and the common effect conditional on $S_{i j 0}$, is null by construction. Hence the estimator for the $T T$ effect is consistent if $\mathrm{E}\left(\varepsilon_{i j t} \mid \phi_{i j}, \beta_{j t}, \gamma_{j t} S_{i j 0}, P_{i j t}\right)=0$.

This specification thus provides an unbiased estimate of the $T T$ effect when the selection of beneficiaries is based on an individual's fixed characteristics, time fixed effects specific to the pre-treatment dropout histories, or of course any other variable unrelated to school dropout behavior. In this specification, the average impact of the program on the selected children of a municipality is identified by within-person comparisons of changes in dropout rates with that of 
non-beneficiary children of the municipality with the same pre-program dropout status. ${ }^{14}$ In the empirical analysis, pre-program status is observed in both 1999 and 2000. With this approach, we estimate an average $T T$ impact for each municipality.

To further justify our identification assumption, we present two additional robustness tests. First, we re-estimate the model in equation (1) matching on beneficiaries and nonbeneficiaries with the exact same pre-program dropout histories (Card and Sullivan, 1988). While similar to equation (3), this model relaxes the functional form assumption and restricts the estimates to areas of common support. Second, with two years of pre-program data, we compare the changes in dropout rates between 1999 and 2000 for future beneficiaries and nonbeneficiaries. This is given by the difference-in-difference estimator for each municipality as follows:

$$
S_{i j t}=\alpha_{i j}+\gamma_{j} T_{00}+\theta_{j} B_{i j} T_{00}+\mu_{i j t}, \text { for } t=1999,2000,
$$

where $B_{i j}$ represents the status of future beneficiary and $T_{00}$ is a dummy variable for year 2000 . This allows us to not only test for differential trends in pre-program dropout behavior between beneficiaries and non-beneficiaries, but also to test whether the program effects are different when we restrict the estimation sample to those municipalities without differential pre-program trends. Thus, our final specification estimates the program effects conditional on child fixedeffects, and differential time effects by pre-program dropout histories, and for the subset of municipalities where pre-program trends in dropout behavior were not different between beneficiaries and non-beneficiaries.

\section{The impact of Bosla Escola on dropout rates}

In this section, we first report the estimation of the average impact over all municipalities in the sample. The estimated impact is robust to various empirical specifications and robustness checks. We then report the variation in program impacts across municipalities.

\section{Average impact on dropout rates}

Table 2 presents regression results from estimating several variants to equation (3), where the dependent variable is a binary variable for whether or not the child drops out of school during the school year as reported in the school records. Column (1) presents an estimate of the

\footnotetext{
${ }^{14}$ This will control for any reversion to the mean if selection was based on the dropout status. Note that in this particular case, where beneficiaries have much lower dropout rate than non-beneficiaries, a reversion to the mean would suggest that we were under-estimating the program's impact.
} 
treatment effect that only includes year and individual child fixed effects. Under this specification, Bolsa Escola reduced dropout rates among beneficiary children by 5.7 percentage points. But, as we discussed above, a causal interpretation of this estimate assumes that program beneficiaries were not selected based on pre-program dropout behavior.

In columns (2) to (5), we relax this assumption by extending the fixed-effects model to allow for children with different pre-treatment dropout status to experience different year effects (equation (3) above). In column (2), the model allows for different year effects based on dropout status in 2000 (the year before the program started), whereas the model presented in column (3) allows for time effects to vary with both child 1999 and 2000 dropout status. Column (4) presents a model that allows for separate time effects for each of the four possible combinations of dropout histories in 1999 and 2000. Column (5) presents the most flexible specification. Here we estimate the model presented in column (1) separately for each of the four dropout histories and compute the overall treatment effect by weighting the results for each of the individual dropout histories by the sample fractions.

Overall, the estimates suggest that Bolsa Escola reduced dropout rates by around 8 percentage points for its selected beneficiaries. The point estimates are highly statistically significant and change little across the various specifications. The results imply that if it were not for the program, we would have observed a dropout rate of 12 percent instead of the 4 percent observed among beneficiaries in 2001-2003. The program thus induced a substantial $66 \%$ percent decline in dropout.

Columns (6) and (7) present further robustness checks by restricting the sample to municipalities where pre-program trends verify the assumption underlying the identification. In column (6), the estimation is performed on the 194 municipalities where the pre-program differences in change in dropout rates between (future) beneficiaries and non-beneficiaries are not significantly different. In column (7), we restrict the sample to the 111 municipalities where beneficiaries had a higher increase in dropout rates than non-beneficiaries in the pre-program period. In both cases, the estimated impact on beneficiaries is basically the same as when estimated on the whole sample in columns (2) to (5).

To further verify that the program's impact is not confounded with possible differential quitting rates for beneficiaries and non-beneficiaries, we estimated the treatment effect on the sub-sample of 16564 children enrolled in all 5 years. Note that this sample has a different age structure than the population at large, with no older children in the earlier years and no young children in the later years. However, the results (not reported in the table) are quite similar, with an estimated $T T$ effect of -5.6 percentage points in spite of a very different population sample. 


\section{Estimation of municipal-level impacts on dropout rates}

The Bolsa Escola program reduced dropout rates by 8 percentage points on average. Program impact varies, however, considerably across municipalities. Our survey design allows to estimate an impact $\bar{\theta}_{j}$ of the program for each municipality $j$. Figure 1 presents the frequency distribution of these program impacts $\bar{\theta}_{j}$ on dropout rates, using the econometric specification presented in column 2 of Table 2 for each of the 261 municipalities. The distribution of impacts is skewed towards negative values with a median impact of -6.7 percentage points. While the estimated impacts range from -25.5 to 10.7 percentage points, over 95 percent are negative. In addition to the distribution of unbiased estimates of impact, Figure 1 plots the absolute values of the corresponding t-statistics. Each circle represents the estimated impact for one municipality, with the point estimate reported on the horizontal axis and its corresponding t-statistic on the vertical axis. Few positive impacts are measured precisely. ${ }^{15}$ Over 55 percent of the estimates are significantly negative at the 5 percent level and 65 percent at the 10 percent level. Given the substantial variation in program performance across municipalities, a natural question to ask is to what extent electoral incentives affect program performance across municipalities.

\section{Impact of electoral incentives on municipal program performance}

In this section, we provide evidence consistent with theory that the program performed better in municipalities where mayors faced re-election incentives. To estimate these effects of electoral accountability, we compare the program's impact on dropout rates in municipalities where the mayor happened to be serving in his first term (and hence could be re-elected) to those where the mayor happened to be serving in his second (and thus final) term at the time when the program was introduced. Although the difference in program impacts between first and second-term mayors will capture the effects of re-election incentives, it is potentially confounded by at least two factors. First, given that second-term mayors are a selected group, it is likely that they are more politically able than first-term mayors. If political ability is positively correlated with program performance, then the simple difference will be biased upwards, meaning we will underestimate the reduction in dropout rate. Second, second-term mayors by construction have more consecutive years of experience in office than first-term. Without controlling for these

\footnotetext{
${ }^{15}$ As can be seen in Figure 2, only one positive impact is significantly different from 0 at the 10 percent level and the rest have an average t-statistic of 0.80 .
} 
potential differences in experience, estimates will again be upwardly biased. To see this more explicitly, consider the following regression model:

$$
\bar{\theta}_{j}=\alpha+\beta^{*} R_{j}+X_{j} \delta+\gamma_{1} \text { Ability }_{j}+\gamma_{2} \text { Experience }_{j}+\varepsilon_{j},
$$

where $R_{j}$ is a dummy variable equal to 1 if the mayor is in his first term, the $X_{j}$ are municipal and mayor characteristics, and $\beta^{*}$ is expected to be negative if first-term mayors obtain a higher reduction in dropout. Thus assuming that $\gamma_{1}$ and $\gamma_{2}$ are negative, then $\beta>\beta^{*}$, where $\beta$ is the first-term effect on performance without controlling for ability and experience. Not controlling (or controlling incompletely) for ability and experience would thus yield an upward bias. The favorable effect of first-term on the decline in dropout rate would be under-estimated.

These biases may not be of concern in identifying the role of electoral incentives on performance as they affect performance in the opposite direction. However, to account for these potential biases, we follow Ferraz and Finan (2008) and employ two strategies. First, we compare second-term mayors to the set of first-term mayors who were re-elected in the subsequent election. If the bias from the OLS regression comes from unobserved political ability that positively selects more able politicians into a second-term, this approach controls for a significant portion of this bias by comparing mayors that are as politically able as second-term mayors. Second, in comparing first and second-term mayors, we can account for the effects of political experience by restricting the sample to first-term mayors that have had at least two terms of political experience in another office.

There is another confounding factor for which we cannot control, but it would again increase second term performance, running opposite to our electoral incentives model. Mayors may control other resources that they can use to compensate qualifying households who did not receive a Bolsa Escola stipend in a way that induces them to stay at school. This would lower the estimated impact of Bolsa Escola on drop out. If first-term mayors are more likely to compensate non-beneficiaries because of re-election incentives, we would be under-estimating the impact of electoral incentives on performance.

Table 3 presents regression results from estimating several specifications based on equation (5). ${ }^{16}$ The dependent variable in each regression is the program's impact on dropout rate

\footnotetext{
${ }^{16}$ We purposefully chose to first estimate the program impact at the municipality level and then estimate the impact of mayors' electoral status on this impact, because this is what best corresponds to the fact that municipalities are independent of each others in their management of the program. The alternative of a joint estimation over all municipalities, such as $S_{i j t}=\phi_{i j}+\left(\theta_{1}+\theta_{2} R_{j}\right) P_{i j t}+\mu_{i j t}$, implies assuming a distribution for $\mu_{i j t}$ that is common to all $i j t$ observations, which is not the same as assuming one distribution per
} 
for a particular municipality. Column (1) reports the unadjusted relationship between program impact and whether the mayor happens to be in his first term which shows a 2 percentage points gain in reducing dropout. Columns (2) and (3) include additional sets of controls. In column (2), we account for differences in municipal and mayor characteristics and introduce state fixed effects. Column (3) includes other municipal characteristics that although endogenously determined might proxy for some unobserved determinants of program performance. As seen across both columns, the inclusion of these additional controls has virtually no effect on the original estimate. For instance under the most flexible specification (column 3), the point estimate is -0.021 which is statistically significant at the $1 \%$ level. This stability of the parameter to the addition of many mayor and municipal characteristics gives confidence that the estimated effect is likely not due to omitted variable bias. At an average impact of -6.7 percentage points across all municipalities -- with -7.9 percentage points in municipalities with first term mayors and -5.9 percentage points in municipalities with second term mayors --, this 2.1 percentage points gain in program performance corresponds to a 36 percent better performance for first term mayors.

In columns (4) and (5), we examine the extent to which political ability and experience may be biasing our results. Column (4) reports the results from the comparison of first-term mayors that were re-elected in the subsequent 2004 elections to the subset of second-term mayors. Using this sample of mayors, we find that re-election incentives improve program performance by 2.6 percentage points, which is statistically similar to our base specification. To account for any potential differences in experience between first and second-term mayors, we compare in column (5) the subset of first-term mayors that have had at least 2 terms of political experience as either a local legislator or a state or federal congressman to second-term mayors. Although we control for political experience in column (2) (and find that the estimates are robust), this comparison excludes first-term mayors that have less political experience than second-term mayors. The results are consistent with the previous specifications.

Column (6) in Table 3 introduces governance practices that are correlated with program impact. The program performs worse among municipalities with higher levels of nepotism or cronyism, as measured by whether the mayor's spouse is also a politician, the share of employees in the mayor's office who are related to the mayor, and the share of secretariat members who are politicians rather than technicians (positive but not significant). We find that even after

municipality in the model $S_{i j t}=\phi_{i j}+\theta_{j} P_{i j t}+\mu_{i j t}$. The OLS estimators of these two models are different as they verify $\bar{S}=\bar{\phi}+\hat{\theta}_{1} \bar{P}+\hat{\theta}_{2} \overline{R P}$ and $\bar{S}=\bar{\phi}+\left(\hat{\theta}_{1}+\hat{\theta}_{2} \bar{R}\right) \bar{P}_{j}$, respectively. 
accounting for these symptomatic features of bad governance, that hold for both first and secondterm mayors, the effect of re-election incentives remains unaltered.

\section{Interpreting the results}

In interpreting the results, there are two issues that need to be verified. The first is that there are indeed electoral rewards to good program performance, suggesting that the electorate is

informed about performance and cares about it in casting their votes. The second is to explore what do first-term mayors do to achieve a higher performance.

\section{Electoral rewards to good program performance}

The results thus far correspond to a simple model of political agency. It requires that voters are informed of and care about the program's impact, and mayors with re-election incentives exert effort on program delivery in order to increase their chances of re-election. A prediction of this model is that first-term mayors are more likely to get re-elected in municipalities where the program performed better. Clearly, re-election responds to the quality of performance in a broader set of public functions which are presumably correlated with effective management of the Bolsa Escola program.

Figure 2 shows a non-parametric estimate of the unconditional relationship between program impact and probability of reelection among incumbent mayors in the 2004 election. It indicates a clear upward trend for mayors who have achieved a program impact below -0.09 , which corresponds to the top 25 percent in the distribution of program impacts.

We verify this result in a regression framework in Table 4. The electorate may have difficulty recognizing a mayor's program performance (as can be seen from the non-significant coefficients in columns (1) and (2)), unless performance is outstanding. This would be the case for the top 25 percent mayors with the largest program impacts (columns (3) and (4)). We see that these incumbent mayors have a 28 percent greater chance of being re-elected. The electorate can also see how the program was administered, in particular whether children that did not qualify were included (type II error). The results in columns (5) and (6) show that mayors with no public denouncements of inclusion errors have a 26 percent higher chance of re-election. When put together in columns (7) and (8), these results are robust. We can thus conclude that re-election is associated with good performance in managing Bolsa Escola in accordance with federal program objectives, likely symptomatic of good performance in broader public functions as well. The 
electorate thus seems to be informed about program performance and concerned with it in casting their votes in local elections.

\section{What do first-term mayors do differently to achieve a higher performance?}

Mayors have considerable leeway in choosing the institutional set up to implement the Bolsa Escola program, and there are large variations in practices across municipalities. Some of these practices are clearly associated with better and worse program performance. The question is whether the positive correlates of performance are more prevalent with first than second-term mayors, and correspondingly the negative correlates less prevalent.

Many of the municipal practices that are associated with a higher program impact have to do with greater transparency in program implementation. As can be seen in panel A of Table 5, this includes registering beneficiaries in schools as opposed to less neutral sites such as the mayor's office. It also involves verifying the information provided by parents about their selfdeclared poverty status. And it implies having social councils composed of citizens and public officials that can effectively deliberate implementation procedures. All these practices bear positively on program performance, reducing the dropout rate. In terms of enforcement of program rules, the practice associated with lower dropout rates involves not sending a program coordinator to visit the household when conditionalities are not met as opposed to strict application of rules. Panel B of Table 5 shows that these favorable practices in program implementation (a deliberative social council) are used more frequently by first-term mayors, and unfavorable practices (coordinator visits) less frequently, suggesting the channels through which first-term gains in performance occur.

\section{Conclusion}

Bolsa Escola was a decentralized conditional cash transfer program aimed at reducing school drop-out rates among the children of the poor, with municipal authorities in charge of program implementation. The federal government thus sought to achieve higher program performance by entrusting local politicians with the selection of beneficiaries and the enforcement of rules. The expectation is that this gives citizens the opportunity of holding local politicians accountable for program performance, thereby creating an incentive for politicians with re-election concerns to increase effort in achieving high program performance. The Bolsa Escola experience is thus symptomatic of a broad trend toward increasing decentralization in the provision of local public 
goods. It provides a rare opportunity to understand empirically how local electoral incentives can affect decentralized program performance.

We find that, while Bolsa Escola had a strong overall impact on beneficiary school attendance, reducing dropout rates by 8 percentage points, municipalities governed by mayors with re-election incentives fared much better. Compared to mayors in their second and final term, first-term mayors achieved a 36 percent greater program impact. This finding is robust to the introduction of state fixed effects, municipal and mayor characteristics, and local governance practices. It is also robust to comparing the performance of first-term mayors who will win reelection, or of those with similar political experience, to that of second-term mayors. In addition, remaining effects on performance due to ability and experience run opposite to the electoral incentive effect, and would induce a downward bias on the estimate of this effect. The same applies to other factors that can affect mayors' performance such as compensating nonbeneficiaries with other resources and seeking first-term clientelistic gains in selecting children.

Consistent with model predictions, we see that superior performance is rewarded in the electoral boots, suggesting that the electorate is informed of and concerned with program performance in casting their votes at re-election time. Mayors with the 25 percent highest program impacts have a 28 percent greater chance of re-election. Those with no public denouncements of inclusion errors have a 26 percent higher probability of being re-elected. Firstterm mayors are more likely to adopt specific program implementation practices that are not only more transparent but also associated with superior program performance.

Overall our findings support the proposition that electoral incentives can play a central role in the success of decentralized delivery of local public goods. The presence of formal local institutions, particularly electoral rules that enable voters to reward and punish locally-elected officials, is key for reaping the benefits that decentralization can provide. When constitutional rules do not support electoral accountability, introducing other mechanisms of political rewards and citizen control becomes all the more important.

\section{References}

Abramovay, Miriam, Carla Andrade, and Julio Jacobo Waiselfisz. 1998. Bolsa Escola: Melhoria Educacional e Redução da Pobreza. Brasilia: UNESCO.

Aguiar, Marcelo, and Carlos Henrique Araújo. 2002. Bolsa Escola: Education to Confront Poverty. Brasilia: UNESCO.

Alderman, Harold. 2002. “Do Local Officials Know Something We Don't? Decentralization of Targeted Transfers in Albania." Journal of Public Economics 83(3): 375-404. 
Alesina, Alberto, and Guido Tabellini. 2007. "Bureaucrats or politicians? Part I: A Single Policy Task." American Economic Review 97(1): 169-179.

Banks, Jeffrey, and R. Sundaram. 1993. "Adverse Selection and Moral Hazard in a Repeated Elections Model.” In W. Barnett et al., eds., Political Economy: Institutions, Information, Competition, and Representation. Cambridge: Cambridge University Press.

Bardhan, Pranab. 2002. "Decentralization of Governance and Development." Journal of Economic Perspectives 16(4): 185-205.

Bardhan, Pranab, and Dilip Mookherjee. 2006. "Pro-poor Targeting and Accountability of Local Governments in West Bengal." Journal of Development Economics 79(2): 303-327.

Barro, Robert. 1973. "The Control of Politicians: An Economic Model." Public Choice 14: 19-42. Besley, Timothy, and Ravi Kanbur. 1993. "Principles of Targeting.” In M. Lipton and J. van der Gaag, eds., Including the Poor. Washington D.C.: The World Bank.

Besley, Timothy, and Anne Case. 1995. "Does Electoral Accountability Affect Economic Policy Choices? Evidence from Gubernatorial Term Limits." The Quarterly Journal of Economics 110(3): 769-798.

Besley, Timothy. 2006. Principled Agents? The Political Economy of Good Government. Oxford, UK: The Lindahl Lectures, Oxford University Press.

Bourguignon, François, Francisco Ferreira, and Philippe Leite. 2003. "Conditional Cash Transfers, Schooling, and Child Labor: Micro-Simulating Brazil's Bolsa Escola Program.” World Bank Economic Review 17(2): 229-54.

Card, David, and Daniel Sullivan. 1988. "Measuring the Effect of Subsidized Training Programs on Movements in and out of Employment." Econometrica 56(3): 497-530.

de Janvry, Alain, Frederico Finan, Elisabeth Sadoulet, Donald Nelson, Kathy Lindert, Bénédicte de la Brière, and Peter Lanjouw. 2005. "Brazil's Bolsa Escola Program: The Role of Local Governance in Decentralized Implementation.” Washington D.C.: The World Bank, Social Safety Nets Primer Series.

Faguet, Jean-Paul. 2004. "Does Decentralization Increase Responsiveness to Local Needs? Evidence from Bolivia.” Journal of Public Economics 88(3-4): 867-894.

Ferejohn, John. 1986. "Incumbent Performance and Electoral Control.” Public Choice 50: 5-25.

Ferraz, Claudio, and Frederico Finan. 2008. "Electoral Accountability and Corruption: Evidence from the Audits of Local Governments." Economics Department, University of California at Los Angeles.

Foster, Andrew, and Mark Rosenzweig. 2004. "Democratization and the Distribution of Local Public Goods in a Poor Rural Economy.” Economics department, Brown University. 
Galasso, Emanuela, and Martin Ravallion. 2005. "Decentralized Targeting of an Antipoverty Program.” Journal of Public Economics 89(4): 705-727.

Glewwe, Paul, and Ana Lucia Kassouf. 2008. "The Impact of Bolsa Escola/Familia Conditional Cash Transfer Program on Grade Promotion and Drop Out Rates in Brazil." Paper presented at the Mid-West International Economic Development Conference, Madison, Wisconsin.

Hagopian, Frances. 1996. Traditional Politics and Regime Change in Brazil. Cambridge: Cambridge University Press.

Lindert, Kathy, Anja Linder, Jason Hobbs, and Bénédicte de la Brière. 2006. "The Nuts and Bolts of Brazil's Bolsa Familia Program: Implementing Conditional Cash Transfers in a Decentralized Context." Washington D.C.: The World Bank.

List, John, and Daniel Sturm. 2006. "How Elections Matter: Theory and Evidence from Environmental Policy." Quarterly Journal of Economics 121(4): 1249-1281.

Persson, Torsten, and Guido Tabellini. 2002. Political Economics: Explaining Economic Policy. Cambridge, Massachusetts: MIT Press.

Ravallion, Martin. 2007. "How Relevant is Targeting to the Success of an Antipoverty Program?" World Bank Policy Research Working Paper No. 4385, Washington D.C.

Rose-Ackerman, Susan. 1999. Corruption and Government: Causes, Consequences, and Reform. New York: Cambridge University Press.

Seabright, Paul. 1996. "Accountability and Decentralization in Government: An Incomplete Contracts Model." European Economic Review 40(1): 61-89.

Souza, Paulo Renato. 2005. Revolução Gerenciada: Educação no Brasil 1995-2002. New Jersey: Prentice-Hall.

World Bank. 2003. Making Service Work for Poor People. World Development Report 2004. Washington D.C.: The World Bank. 


\section{Figure 1. Frequency distribution and t-statistics of estimated impacts of Bolsa Escola on}

dropout rates by municipality

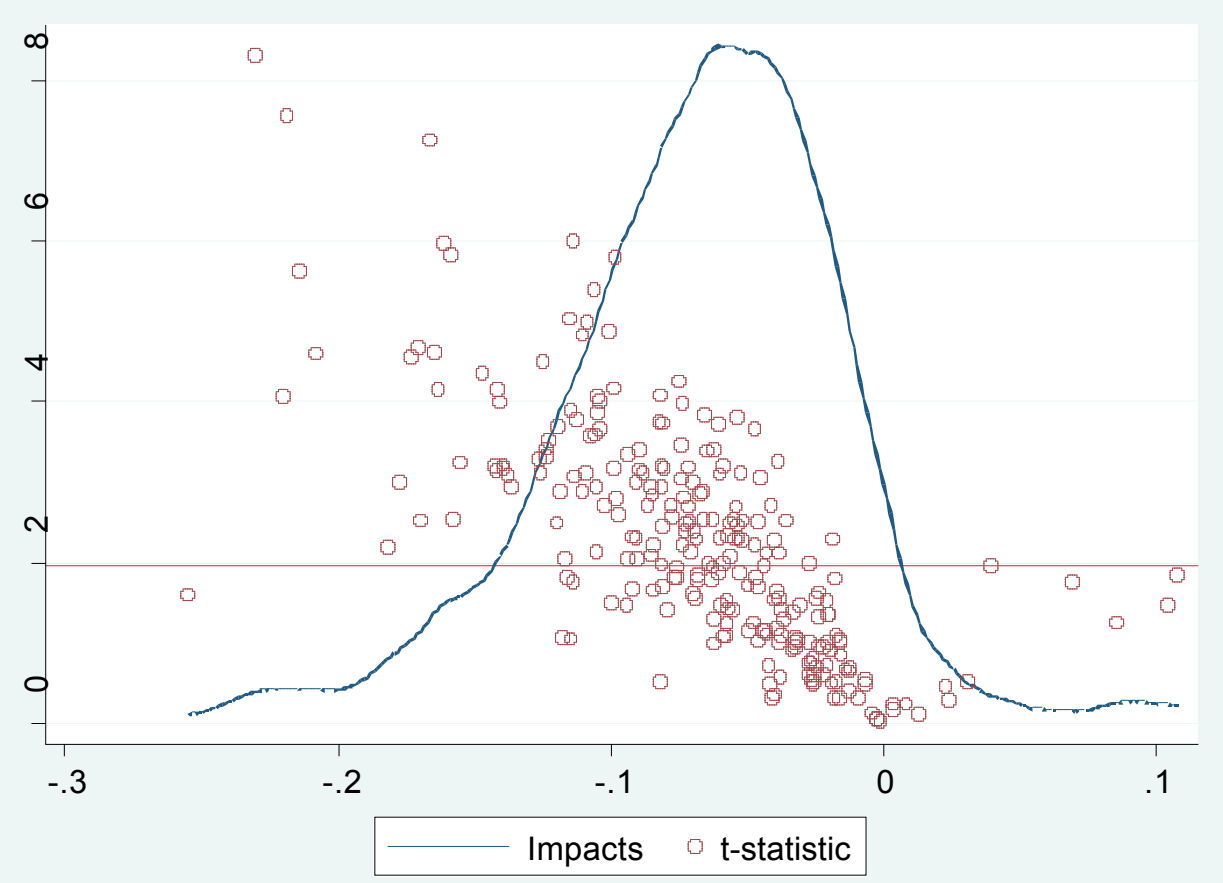

Notes: Each circle represents the impact for one municipality, with the point estimate on the horizontal axis and the absolute value of the associated t-statistic on the vertical axis. The horizontal line at $t=1.96$ delineates the 10 percent significance level. The frequency distribution is of the impact point estimates in the sample of municipalities. 
Figure 2. Reelection rates by program impact

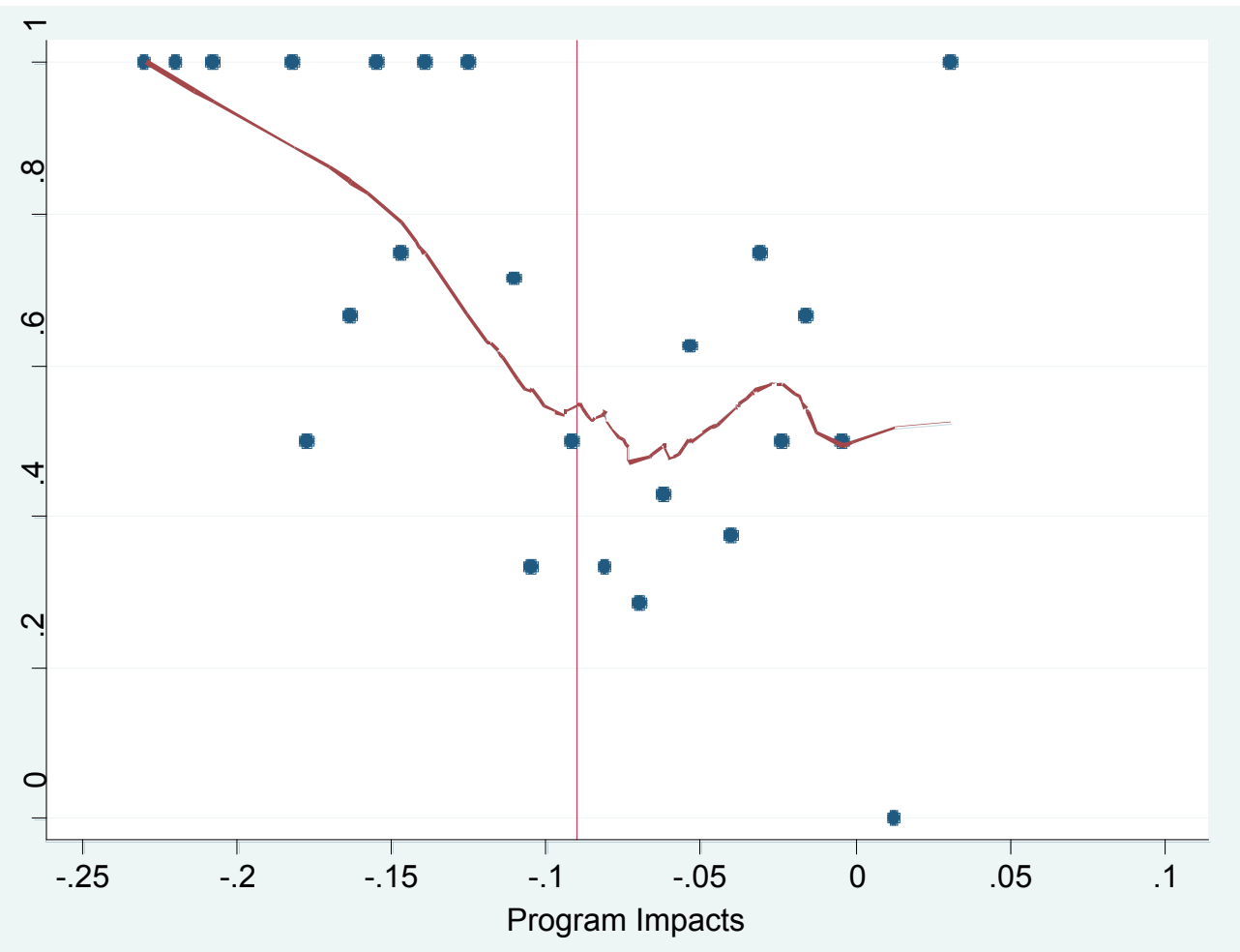

Notes: The Figure shows reelection rates in 2004 by program impact. The plot presents the proportion of first-term mayors that were re-elected in 2004 for a bin size of 0.01 impact (circles) along with a locally weighted regression calculated with a bandwidth of 0.8 . Municipalities to the left of the vertical line were in the top 25 percent in terms of program impact. 
Table 1. Dropout rates

\begin{tabular}{lc}
\hline \hline Year & $\begin{array}{c}\text { Dropout } \\
(\%)\end{array}$ \\
\hline 1999 & 14.2 \\
2000 & 15.0 \\
\hline 2001 & 13.2 \\
2002 & 12.8 \\
2003 & 13.3
\end{tabular}

Pre-program (1999 and 2000)

Bolsa Escola beneficiaries

4.4

Non beneficiaries

17.1

Dropout is defined as dropping out before the end of the school year.

Table 2. Average impact of Bolsa Escola on dropout rates

\begin{tabular}{|c|c|c|c|c|c|c|c|}
\hline Dependent variable: Dropout (1/0) & $(1)$ & (2) & (3) & (4) & $(5)$ & $(6)$ & $(7)$ \\
\hline Treatment effect & $\begin{array}{c}-0.057 \\
{[0.003]^{* *}}\end{array}$ & $\begin{array}{c}-0.080 \\
{[0.004]^{* *}}\end{array}$ & $\begin{array}{c}-0.085 \\
{[0.004]^{* *}}\end{array}$ & $\begin{array}{c}-0.085 \\
{[0.005]^{* *}}\end{array}$ & $\begin{array}{c}-0.096 \\
{[0.004]^{* *}}\end{array}$ & $\begin{array}{c}-0.074 \\
{[0.008]^{* *}}\end{array}$ & $\begin{array}{c}-0.092 \\
{[0.016]^{* *}}\end{array}$ \\
\hline Year fixed effects & Yes & Yes & Yes & Yes & Yes & Yes & Yes \\
\hline Child fixed effects & Yes & Yes & Yes & Yes & Yes & Yes & Yes \\
\hline Dropout status in $2000 *$ Year effects & No & Yes & Yes & $\mathrm{n} / \mathrm{a}$ & $\mathrm{n} / \mathrm{a}$ & $\mathrm{n} / \mathrm{a}$ & $\mathrm{n} / \mathrm{a}$ \\
\hline Dropout status in $1999 *$ Year effects & No & No & Yes & $\mathrm{n} / \mathrm{a}$ & $\mathrm{n} / \mathrm{a}$ & $\mathrm{n} / \mathrm{a}$ & $\mathrm{n} / \mathrm{a}$ \\
\hline Dropout history * Year effects & No & No & No & Yes & $\mathrm{n} / \mathrm{a}$ & Yes & Yes \\
\hline Mean of dependent variable & 0.137 & 0.116 & 0.116 & 0.116 & 0.116 & 0.114 & 0.150 \\
\hline Number of children & 290517 & 118234 & 118234 & 118234 & 118234 & 78737 & 16437 \\
\hline Observations & 604561 & 344107 & 344107 & 344107 & 344107 & 229720 & 33308 \\
\hline R-squared & 0.72 & 0.69 & 0.73 & 0.73 & $\mathrm{n} / \mathrm{a}$ & 0.68 & 0.77 \\
\hline
\end{tabular}

Robust standard errors clustered at the municipality level in brackets. + significant at $10 \% ; *$ at $5 \% ; * *$ at $1 \%$

The sample in columns (2) to (5) is restricted to children that are in school in 1999 and 2000.

Samples in columns (6) and (7) correspond to the municipalities where difference in pre-program dropout trends for beneficiaries and non-beneficiaries are not statistically different (in col. 6) and are greater than 0 (in col. 7).

n/a: not applicable 


\section{Table 3. Effects of electoral incentives on program performance}

\begin{tabular}{|c|c|c|c|c|c|c|}
\hline Dependent variable: Program's impact on dropout rate & $(1)$ & $(2)$ & $(3)$ & $(4)$ & $(5)$ & $(6)$ \\
\hline Mayor in first term & $\begin{array}{c}-0.020 \\
{[0.008]^{*}}\end{array}$ & $\begin{array}{c}-0.022 \\
{[0.007]^{* *}}\end{array}$ & $\begin{array}{c}-0.021 \\
{[0.007]^{* *}}\end{array}$ & $\begin{array}{c}-0.026 \\
{[0.009]^{* *}}\end{array}$ & $\begin{array}{c}-0.018 \\
{[0.010]+}\end{array}$ & $\begin{array}{c}-0.020 \\
{[0.007]^{* *}}\end{array}$ \\
\hline \multicolumn{7}{|l|}{ Governance practices } \\
\hline Mayor's spouse is a politician & & & & & & $\begin{array}{c}0.018 \\
{[0.010]+}\end{array}$ \\
\hline Share of public employees related to the mayor & & & & & & $\begin{array}{c}0.178 \\
{[0.062]^{* *}}\end{array}$ \\
\hline Share of secretariat that are politicians (vs. technicians) & & & & & & $\begin{array}{c}0.020 \\
{[0.012]}\end{array}$ \\
\hline Municipal characteristics & No & Yes & Yes & Yes & Yes & Yes \\
\hline Mayor characteristics & No & Yes & Yes & Yes & Yes & Yes \\
\hline Other municipal characteristics & No & No & Yes & Yes & Yes & Yes \\
\hline State fixed effects & No & Yes & Yes & Yes & Yes & Yes \\
\hline Mean of dependent variable & -0.067 & -0.067 & -0.067 & -0.067 & -0.064 & -0.067 \\
\hline Observations & 236 & 236 & 236 & 193 & 176 & 236 \\
\hline R-squared & 0.03 & 0.27 & 0.31 & 0.38 & 0.32 & 0.34 \\
\hline \multicolumn{7}{|c|}{$\begin{array}{l}\text { Robust standard errors in brackets. }+ \text { significant at } 10 \%, * \text { at } 5 \%, \text { and } * * \text { at } 1 \% . \\
\text { Mayor characteristics include gender, education, number of terms held in a political position, age, and party affliliation dummies. Municipal characteristics } \\
\text { include population density (pop/km), number of districts, \% rural, \% literate population, log per capita income, margin of victory in the previous election, and } \\
\text { gini coefficient. Other municipal characteristics include: existence of an NGO, share of children benefited by the program, municipality is a judiciary district, } \\
\text { existence of social council, received training, number of radios, number newspapers, public sector employment (as share of population), total number of } \\
\text { employees in the mayor's office, and total number of secretariats. }\end{array}$} \\
\hline
\end{tabular}

Table 4. Electoral rewards and program performance

\begin{tabular}{|c|c|c|c|c|c|c|c|c|}
\hline Dependent variable: Mayor was reelected in 2004 & $(1)$ & (2) & (3) & (4) & 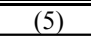 & (6) & $(7)$ & $(8)$ \\
\hline Program impact & $\begin{array}{l}-1.251 \\
{[0.866]}\end{array}$ & $\begin{array}{l}-1.227 \\
{[1.296]}\end{array}$ & & & & & & \\
\hline In top 25 percent of program impacts $(0 / 1)$ & & & $\begin{array}{c}0.234 \\
{[0.108]^{*}}\end{array}$ & $\begin{array}{c}0.282 \\
{[0.142]+}\end{array}$ & & & $\begin{array}{c}0.249 \\
{[0.107]^{*}}\end{array}$ & $\begin{array}{c}0.248 \\
{[0.145]+}\end{array}$ \\
\hline No public denouncement of Type II (inclusion) errors & & & & & $\begin{array}{c}0.172 \\
{[0.106]}\end{array}$ & $\begin{array}{c}0.261 \\
{[0.131]+}\end{array}$ & $\begin{array}{c}0.191 \\
{[0.103]+}\end{array}$ & $\begin{array}{c}0.224 \\
{[0.129]+}\end{array}$ \\
\hline Municipal characteristics & No & Yes & No & Yes & No & Yes & No & Yes \\
\hline Mayor characteristics & No & Yes & No & Yes & No & Yes & No & Yes \\
\hline State fixed effects & No & Yes & No & Yes & No & Yes & No & Yes \\
\hline Observations & 98 & 98 & 98 & 98 & 98 & 98 & 98 & 98 \\
\hline R-squared & 0.02 & 0.3 & 0.05 & 0.33 & 0.03 & 0.33 & 0.09 & 0.36 \\
\hline
\end{tabular}

Observations are for municipalities with incumbent mayor in the 2004 elections.

Robust standard errors in brackets. + significant at $10 \%$; * significant at $5 \%$; ** significant at $1 \%$.

Municipal and mayor characteristics as defined in footnote of Table 3. 
Table 5. Correlates of program implementation methods and program performance (Panel A) and correlates of electoral incentives and choice of program implementation methods (Panel B)

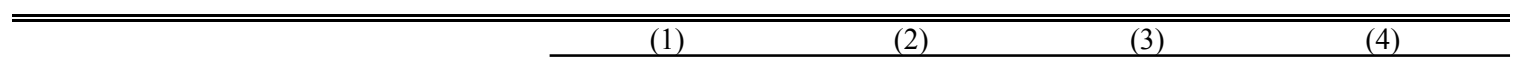

Panel A: Correlates of program implementation methods and performance Dependent variable:

Program performance

Registered beneficiaries in schools $\quad-0.027$

Received visit from program coordinator $\quad[0.012]^{*}$

when conditionalities were not met

Verified information given by parents $-0.015$

Proportion of social councils that are deliberative $[0.007]+$

Proportion of social councils that are deliberative

R-squared

0.31

0.30

0.30

$-0.017$

$[0.009]+$

0.30

Panel B: Correlates of electoral incentives and choice of program implementation methods

\begin{tabular}{|c|c|c|c|c|}
\hline Dependent variable: & $\begin{array}{c}\text { Registered } \\
\text { beneficiaries in } \\
\text { schools }\end{array}$ & $\begin{array}{c}\text { Received visit from } \\
\text { program } \\
\text { coordinator } \\
\end{array}$ & $\begin{array}{c}\text { Verified } \\
\text { information }\end{array}$ & $\begin{array}{c}\text { Proportion of } \\
\text { deliberative social } \\
\text { councils }\end{array}$ \\
\hline Mayor in first term & $\begin{array}{c}0.041 \\
{[0.050]}\end{array}$ & $\begin{array}{c}-0.199 \\
{[0.072]^{* *}}\end{array}$ & $\begin{array}{l}-0.020 \\
{[0.071]}\end{array}$ & $\begin{array}{c}0.139 \\
{[0.057]^{*}}\end{array}$ \\
\hline $\begin{array}{l}\text { Mean of dependent variable } \\
\text { R-squared }\end{array}$ & $\begin{array}{c}0.849 \\
0.19\end{array}$ & $\begin{array}{c}0.441 \\
0.22\end{array}$ & $\begin{array}{c}0.638 \\
0.19\end{array}$ & $\begin{array}{c}0.645 \\
0.14\end{array}$ \\
\hline \multicolumn{5}{|l|}{ Controls for both panel estimations } \\
\hline Municipal characteristics & Yes & Yes & Yes & Yes \\
\hline Mayor characteristics & Yes & Yes & Yes & Yes \\
\hline Other municipal characteristics & Yes & Yes & Yes & Yes \\
\hline State fixed effects & Yes & Yes & Yes & Yes \\
\hline Observations & 232 & 236 & 235 & 236 \\
\hline
\end{tabular}

Robust standard errors in brackets.+ significant at $10 \% ; *$ at $5 \% ; * *$ at $1 \%$

Municipal and mayor characetristics as defined in Table 3. 